\title{
Friend Murine Leukemia Virus
}

National Cancer Institute

\section{Source}

National Cancer Institute. Friend Murine Leukemia Virus. NCI Thesaurus. Code C14362.

A murine leukemia virus producing leukemia of the reticulum-cell type with massive infiltration of liver, spleen, and bone marrow. It infects DBA/2 and Swiss mice. 